\title{
Dividend Taxation and the Cost of New Share Issues*
}

\author{
Tobias Lindhe† and Jan Södersten
}

October 2015

That the dividend tax reduces the rate of return to investments financed by new issues of equity, and hence raises the cost of capital, has generally been accepted in earlier research. Still, and virtually without discussion, the existing literature has come to widely diverging conclusions about the size of the tax distortion. We demonstrate that the extent to which shareholders can recover their original equity injections without being subject to tax is a key factor in determining the cost of new equity. Our analysis explains for the first time why the earlier literature has come to diverging conclusions about the size of the tax distortion.

JEL Classification: $H 24, H 25, H 32$

Keywords: dividend taxation, return of capital, share repurchases, equity trap, cost of capital, nucleus theory, growth path

*We are grateful to Martin Jacob, Michael Riis Jacobsen, Sven-Olof Lodin, Guttorm Schjelderup, Vesa Kanniainen and Chuan-Zhong Li for helpful suggestions.

$\dagger$ Uppsala Center for Fiscal Studies (UCFS), Uppsala University, Tobias.Lindhe@ telia.com

† Corresponding author: Uppsala Center for Fiscal Studies (UCFS), Department of

Economics, Uppsala University, Box 75120 Uppsala. E-mail: Jan Sodersten@nek.uu.se 


\section{Introduction}

This paper reconsiders the impact of dividend taxation on the cost of capital when the firm is using new share issues as the marginal source of funds. That the dividend tax reduces the rate of return to investments financed by new issues of equity, and hence raises the cost of capital, has generally been accepted in earlier research. ${ }^{1}$ Still, and virtually without discussion, the existing literature has come to widely diverging conclusions about the size of the tax distortion. $^{2}$

A closer inspection of the literature shows that two different approaches to the theoretical modeling of the impact of the dividend tax have been used. The first of these typically constrains new issues to be non-negative. This modelling requirement seems to have been introduced to prevent the firm from circumventing dividend taxation, but combined with the absence of any explicit provision for a tax-free recovery of original equity, it effectively turns the dividend tax into a combination of a tax on (distributed) profits and a capital levy on issues of new equity. Examples of this approach include well-known contributions by Auerbach (1983) and Sinn (1991), but also more recent papers by Brys and Bovenberg (2006), Chetty and Saez (2007), Korinek and Stiglitz (2009) and Kari and Laitila (2015).

In the second modeling approach, the shareholders - implicitly, as in models in the King and Fullerton (1984) tradition ${ }^{3}$, or explicitly, as in Devereux and Griffith $(1998,2003)$ and Chetty and Saez $(2010)^{4}$ - are allowed a tax-free recovery of their initial equity. Devereux and Griffith state that most tax systems treat a repurchase of equity at its original price to be a repayment of capital which is not taxed, and Chetty and Saez briefly use similar formulations.

\footnotetext{
1 See for example Auerbach (2002).

${ }^{2}$ See references below. With $r$ as the stockholders' rate of return requirement and $\tau$ as the dividend tax rate, well-known and influential papers derive expressions for the cost of capital with new share issues as the source of funds that range from $r /(1-\tau)$ (as in models in the King and Fullerton (1984) tradition) to $(r+\tau) /(1-\tau)$ (see for example Auerbach (1983) and Korinek and Stiglitz (2009)). An exception to the lack of discussion in the literature is Sinn (1991), who claims that earlier research (for example King and Fullerton (ibid.)) underestimated the true cost of equity. We analyze Sinn's results at the end of Section 2 below.

3King and Fullerton's (1984) formulae for the cost of capital have been put to a widespread use in international comparisons and for policy oriented research, see for example OECD (1991), Jorgenson and Landau (1993) and EU (2001).

4 Note that Chetty and Saez (2010) is the revised and published version of Chetty and Saez (2007). The authors changed their assumption on the tax treatment of return of original equity for the published version.
} 
Hence, the dividend tax is confined to be a tax on (distributed) profits.

This paper demonstrates and compares the impact of dividend taxation on the cost of new share issues under the two approaches outlined above. We demonstrate that the extent to which shareholders can recover their original equity injections from the company without being subject to tax is a key factor in determining the cost of new equity. Our analysis explains for the first time why the earlier literature has come to diverging conclusions about the size of the tax distortion.

We draw on Sinn (1991) and set up a simple dynamic model of an all-equity firm, with a personal tax on dividends as the only tax parameter. The outcome of this model is a "nucleus" theory of the corporation. A firm faced by an initial shortage of retainable profits following a disturbance to the marginal productivity of capital, will let the shareholders inject less than the total amount of funds needed to reach a new long-run equilibrium. The adjustments following the initial distortion take place gradually with no dividends being paid until the firm is in a new long-run equilibrium. ${ }^{5}$

Our model includes two varieties. The first of these is the same as examined by eg. Sinn (1991) and Korinek and Stiglitz (2009), namely where it is impossible for the firm to pay cash to its shareholders that is not taxed as dividends. We will denote this variety of the model the full equity trap-case, or F-case, for short. Following the initial new share issue, the F-case firm embarks upon a growth path using less expensive retained earnings and continues to grow by internal funds, issuing no more shares, and paying no dividends until the marginal productivity of capital is equated to the rate of interest.

The second variety of the model allows the shareholders a tax-free return of the original capital contributed through the new issues. This means that negative new share issues (such as share redemptions or share repurchases or other forms of tax-free cash distributions) are allowed, but only to the extent of the amount contributed by the shareholders. This is the partial equity trap-case, or P-case - reflecting the implicit or explicit assumptions by King-

\footnotetext{
${ }^{5}$ The discussion in the economics literature on the effects of dividend taxation has recently been revitalized, for example by including elements from the corporate finance tradition (eg. Chetty and Saez (2010)). We do not contribute to this important development, as the basic model of corporate taxation is sufficient for our purpose to point out the alternative assumptions in the literature regarding the taxation of the return of original equity. The insights we offer make it clear that the tax incentives must be correctly understood and explicitly accounted for, irrespective of modelling strategy.
} 
Fullerton (1984), Devereux and Griffith $(1998,2003)$ and others. With a partial equity trap (Pcase), there is likewise an internally funded growth path, but this growth path is preceded by a phase where the original capital injected into the firm is repaid to the shareholders.

Our analysis shows that the choice between the $F$ - and $P$-cases makes a substantial difference to our perceptions of the distortive effects of dividend taxation. Though no parametric expressions for the cost of new equity are obtained from the analysis (except in special cases), the marginal productivity of capital subsequent to the issue of new equity is considerably higher in the $F$-case and the initial equity injection is smaller. The gradual adjustment towards the long-run equilibrium obviously causes a loss in output, compared to a hypothetical case where the firms could immediately reach their new long-run capital stocks and output levels. This output loss is clearly much higher in the $F$-case, that is, when there are no provisions for a tax-free return of original equity.

The remainder of this paper is organized as follows. Section 2 presents the theoretical model of an all equity firm, and derives general expressions for the cost of capital for two versions of the model, with and without a provision for a tax-free return of original equity. The results for the cost of new share issues derived in the earlier literature come out as special cases of our general model. Optimal behavior following a new issue of equity is determined in section 3 , which also includes numerical simulations to compare the firm's optimal behavior under the two cases. Section 4 summarizes our findings, and we briefly discuss the empirical relevance of the F-and P-case assumptions found in the literature. We point out that even though the provisions for a tax-exempt return of original equity are varied and may differ between countries, most countries allow for at least some tax-exempt return of original capital. Our tentative conclusion is therefore that the F-case assumption - which turns the dividend tax into a combination of a tax on distributed profits and a capital levy - exaggerates the distortive effects of dividend taxation.

\section{The model}

We derive the firm's cost of capital by setting up a dynamic model in discrete time with a personal tax on dividends $\tau$ as the only tax parameter. The owner is assumed to maximize the after-tax dividend stream given by 


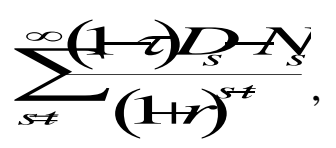

where $D$ denotes dividends as defined in the firm's accounts, $N$ is the amount of new share issues and $r$ is the discount rate. The firm's budget constraint in period $s$ is a cash flow identity, where capital inflow equals capital outflow.

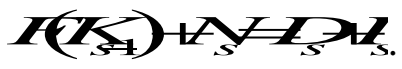

The production function $F(K)$ depends only on the stock of capital, where the stock in period $s-1$ becomes fully efficient in production in period $s$. To keep the model simple, capital depreciation is ignored, which implies that the stock of capital evolves over time as

$$
\boldsymbol{K}_{s-1}+\boldsymbol{I}_{s}=\boldsymbol{K}_{s}
$$

As usual, dividends must be non-negative

$$
D_{s} \geq 0
$$

In the following, we distinguish between two varieties of the model. In the first of these we require issues of new equity to be non-negative

$$
N_{s} \geq 0
$$


Though this constraint is standard in tax models of the firm, its full implication is seldom made clear. With (5), there is no way for the shareholders to withdraw cash from the firm except as dividends. The effect of this is that not only current and past profits (as emphasized by the new view), but also the new issues of equity injected into the firm are trapped by the dividend tax. Put differently, constraint (5) models the dividend tax as a combination of a tax on (distributed) profits and a capital levy on issues of new equity. We will denote this variety of the model the full equity trap-case, or F-case, for short.

The second variety of the model - the partial equity trap-case, or P-case - assumes instead that shareholders are allowed a tax-exempt return of funds injected into the firm by issues of new equity. We model this assumption by letting $A$ be the remaining stock of past (positive or negative) equity injections, and requiring that

$$
A_{s} \geq 0
$$

where the stock $A$ evolves as

$$
A_{S 1}+N_{s}=A_{s}
$$

Constraint (6) implies that negative issues of equity are allowed $(N<0)$, but only within the limit set by the requirement that the sum total of past equity injections (positive or negative) be non-negative. Replacing constraint (5) by constraint (6) and the motion (7) therefore confines the dividend tax to be a tax on distributed profits, leaving any withdrawals of funds to the extent of the original investment of the shareholders free of tax.

The model (for both varieties of the equity trap) defines a discrete-time control problem with control variables $N, D$ and $I$, and state variables $K$ and $A$. By imposing shadow values for the constraints and motions $-\mu^{D}$ for (2), $\mu^{K}$ for (3), $\lambda^{D}$ for (4), $\lambda^{N}$ for (5), $\lambda^{A}$ for (6), $\mu^{A}$ for 
(7) - and maximizing the owners' after-tax dividend stream the optimization problem takes the form $\max \sum_{s=t}^{\infty} \frac{\Lambda()}{(1+r)^{s-t}}$. The $\Lambda$-function reads as

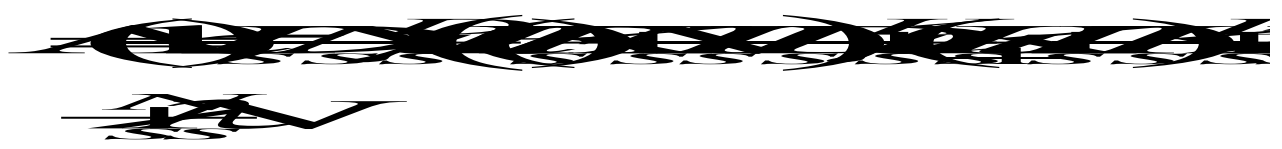

for the $F$-case, and as

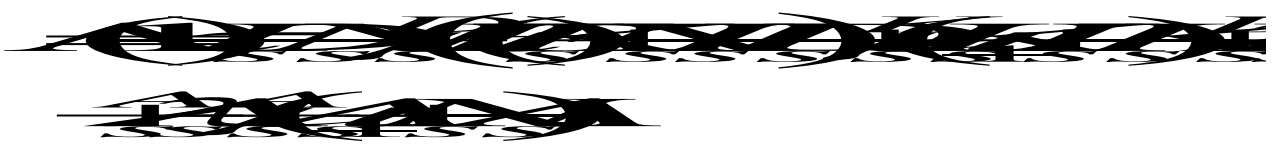

for the $P$-case.

The first order conditions for $D, I$ and $K$ are the same for both varieties of the model

$$
\begin{aligned}
& D_{s} \quad 1+x+\frac{R}{2}= \\
& I_{s} \quad \mu P+\mu k=0
\end{aligned}
$$

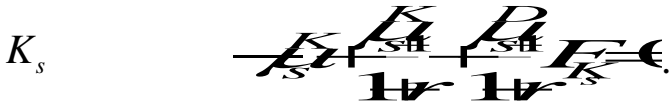

Equations (9) and (10) yield the general expression for the cost of capital

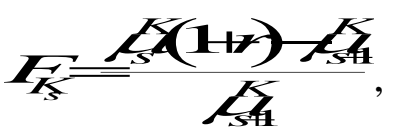


that is, the cost of capital is determined by the rate of interest and the marginal valuation of capital, $\mu^{K}$, for two consecutive periods.

The long-run cost of capital with retained earnings as the marginal source of finance

For a firm that relies on retained earnings as the marginal source of finance and also pays dividends, the shadow value of the dividend constraint appearing in (8) is zero, $\lambda^{D}=0$. Since $\mu^{K}=\mu^{D}$ (eq. 9) the first order condition for $D$ (eq. (8)) then implies that in long-run equilibrium $\mu_{s}^{K}=\mu_{s+1}^{K}=1-\tau$. The general expression for the cost of capital in (11) is therefore

$$
F_{K}=r
$$

With $\mu^{K}=1-\tau$, the owner is indifferent between retaining earnings and receiving dividends, and as a result of this, the dividend tax does not distort the steady state value of the firm's capital stock. This is of course the well-known result from the New View of equity. ${ }^{6}$

New equity as the marginal source of finance

The first order condition specific to the $F$-case is

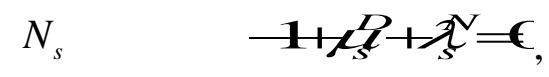

while those specific to the $P$-case are

$N_{s}$

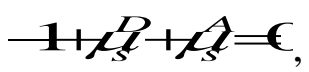

\footnotetext{
${ }^{6}$ The new view of equity was developed by Auerbach (1979), Bradford (1981) and King (1977). For a survey of the debate, see Auerbach (2002) and Auerbach and Hassett (2002, 2005).
} 
$A_{s}$

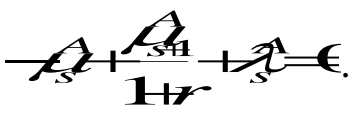

New shares are issued by the firm only occasionally as a response to exogenous disturbances to the productivity of capital when retained earnings are insufficient to finance the required addition to the capital stock. A $F$-case firm hit by a productivity shock in period $t$ will issue new equity sufficient to depress the marginal value of capital to unity, $\mu_{t}^{K}=1^{7}$. The cost of capital associated with the new issue of equity is then obtained from the general expression in (11) as

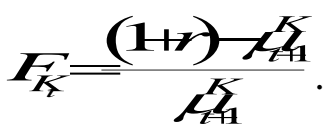

Since the marginal value of capital in the period subsequent to the new issue, $\mu_{t+1}^{K}$, cannot be determined without further assumptions, equation (16) means that no parametric expression for the cost of capital is available for the F-case firm. However, in the special case where the firm pays dividends immediately following the new issue, $\mu_{t+1}^{K}=1-\tau$, and (16) simplifies to

$$
F_{K_{t}}=\frac{r+\tau}{1-\tau}
$$

which corresponds to a result derived by Auerbach (1983, p. 925) and Korinek and Stiglitz (2009, p.143).

When the $P$-case firm issues new shares in period $t$, we assume that $A_{t}>0$. This means that the shadow value $\lambda_{t}^{A}=0$, and by equation (9) and the first order conditions for $N$ and $A$ (eqs. (14) and (15)) we derive $\mu_{t+1}^{K}=\mu_{t}^{K}(1+r)-r$. Using the general expression for the cost of

\footnotetext{
${ }^{7}$ See equations (9) and (13).
} 
capital (eq. (11)) we therefore derive the $P$-case firm's cost of capital following the new equity issue as

$$
F_{K_{t}}=\frac{r}{\mu_{t+1}^{K}}
$$

Again, no parametric expression is available. ${ }^{8}$ In case the firm pays dividends following the new issue, $\mu_{t+1}^{K}=1-\tau$, and we get

$$
F_{K_{t}}=\frac{r}{1-\tau}
$$

as the expression for the cost of capital for a P-case firm. This is King and Fullerton's (1984) well-known expression for the cost of new equity.

For ease of comparison, the expressions for the costs of capital derived above are summarized in Table 1. The character of the equity trap clearly has important implications for the cost of new issues of equity. When the marginal value of capital in the period subsequent to the new issue, $\mu_{t+1}^{K}$, is the same in the two cases, the $F$-case firm has a higher cost of capital. The intuition for this result is particularly clear when the firm pays dividends, see equations (17) and (19). The pre-tax marginal rate of return of the $F$-case firm must then be sufficiently high to compensate not only for the tax on the income from the marginal investment but also for the tax upon the return of the original capital, i.e. the tax code turns the dividend tax into a combination of a tax on (distributed) profits and a capital levy.

\footnotetext{
${ }^{8} \mathrm{~A}$ simple and interesting alternative to (7) would be to let the (net) stock of remaining equity injections, $A$, be augmented annually by stockholders' rate of return requirement, that is $A_{s-1}(1+r)+N_{s}=A_{s}$. Replacing (7) by this motion yields $F_{K_{t}}=r$, that is independent of tax. Such a modified scheme is basically similar to both the Swedish Annell-deduction (a tax benefit based on new issues), see Auerbach (2002), p. 15, and the new Norwegian Shareholder Income Tax, see Sørensen (2005) and Lindhe and Södersten (2012).
} 
Table 1. Cost of new share issues for the full and partial equity trap

\begin{tabular}{|l|l|c|}
\hline & Full Equity Trap $(\boldsymbol{F}$-case) & Partial Equity Trap (P-case) \\
\hline Tax code & $\begin{array}{l}\text { All cash paid to shareholders is } \\
\text { taxed as dividends }\end{array}$ & $\begin{array}{c}\text { Shareholders are allowed a tax-free } \\
\text { return of the original capital }\end{array}$ \\
\hline General: & $\begin{array}{l}\text { (1+r) } \\
\text { S }\end{array}$ & $F_{K_{t}}=\frac{r}{\mu_{t+1}^{K}}$ \\
\hline $\begin{array}{l}\text { Special case: } \\
\text { dividend paying } \\
\text { firm following a } \\
\text { new share issue }\end{array}$ & $F_{K_{t}}=\frac{r+\tau}{1-\tau}$ & $F_{K_{t}}=\frac{r}{1-\tau}$ \\
\hline
\end{tabular}

\section{Sinn's (1991) results reconsidered}

In a well-known and influential paper on dividend taxation, Sinn (1991) finds that, for "mild assumptions" about the form of the firm's production function, the cost of new equity is higher than suggested by conventional formulae, such as that derived by King- Fullerton (see equation 19 above).

Equations (1)-(5) above, which explicitly require new issues of equity to be non-negative, give a discrete-time variant of Sinn's continuous-time model, and the resulting equation (16) for the F-case, corresponds to Sinn's expression for the cost of new equity. In our notation, Sinn's finding is hence that:

$F_{K_{t}}=\frac{(1+r)-\mu_{t+1}^{K}}{\mu_{t+1}^{K}}>\frac{r}{1-\tau}$,

which obviously holds for $\mu_{t+1}^{K} \geq 1-\tau$.

Sinn's explanation to this result is that earlier research underestimated the true cost of equity because it invariably assumed that profits from marginal investment projects were distributed 
as dividends. However, this explanation is misleading. First, as is clear from Table, 1 the left hand side of inequality (20) derives from the F-case, whereas the right hind side is the $P$-case result when the firm pays dividends in the year following the new issue. Sinn's finding, i.e. inequality (20) above, hence reflects an implicit comparison across two different tax regimes with different implications for the equity trap and for the cost of capital. Second, and contrary to Sinn's assertion, the assumption that dividends are paid subsequent to a new issue does not imply a lower cost of capital. With no dividends being paid in the year following the new issue, the shadow value equals $\mu_{t+1}^{K}>1-\tau$, and a simple comparison between (16) and (17) or between (18) and (19) then makes it clear that the cost of capital then is lower than would be the case when the firm pays dividends, that is $F_{K_{t}}=\frac{(1+r)-\mu_{t+1}^{K}}{\mu_{t+1}^{K}}<\frac{r+\tau}{1-\tau}$ for the $F$-case firm and $F_{K_{t}}=\frac{r}{\mu_{t+1}^{K}}<\frac{r}{1-\tau}$ for the $P$-case firm.

This means that optimal behavior, irrespective of tax regime, is associated with a lower cost of capital than follows from a policy of paying dividends subsequent to the new issue.

\section{Optimal behavior and simulation of the growth path}

With a full equity trap, the firm's optimal behavior following a new issue of equity was briefly described in section 1 above, and readers looking for a formal and detailed treatment are referred to Sinn (1991) ${ }^{9}$. This section first explains the incentives faced by the $P$-case firm, and then proceeds to illustrate and compare the optimal behavior of the two types of firms making use of a few numerical simulations.

There are three alternative routes for the $P$-case firm to follow subsequent to a new share issue in period $t$, see the Chart 1 below. We refer to Appendix A for the technical details. We rule out two of these alternatives, which both imply that the firm would maintain a constant and positive stock of new equity $(A>0)$, and use its profits either for paying dividends or for additional investment. Behaving optimally, the $P$-case firm will first use current profits and some disinvestment to undertake a gradual repayment of the original issue of equity. Once the new issue has been repaid $(A=0)$, the firm will retain profits earned in subsequent periods and add to its capital stock. This second phase corresponds to the growth path analyzed by Sinn,

\footnotetext{
${ }^{9}$ A F-case growth-path is derived also in Korinek and Stiglitz (2009), though in terms of money-capital rather than real capital.
} 
where the firm continues to grow by internal funds, paying no dividends until the new longrun equilibrium is reached.

Chart 1. Alternative routes for a $P$-case firm following a new share issue.

\begin{tabular}{|c|c|c|c|}
\hline & \multicolumn{2}{|l|}{ Profit in period $t+1$} & \\
\hline Non-optimal behavior & \multicolumn{2}{|l|}{ Feasible behavior: } & $\underline{\text { Non-optimal behavior }}$ \\
\hline $\begin{array}{l}\text { Use the profits to pay } \\
\text { dividends in period } \\
t+1 \text { and maintain a } \\
\text { positive stock of new } \\
\text { equity. }\end{array}$ & \multicolumn{2}{|l|}{$\begin{array}{l}\text { Use the profits for } \\
\text { repayment in period } \\
t+1 \text { of the initial issue } \\
\text { of equity. }\end{array}$} & $\begin{array}{l}\text { Use the profits for } \\
\text { additional investment } \\
\text { in period } t+1 \text { and } \\
\text { maintain a positive } \\
\text { stock of new equity. }\end{array}$ \\
\hline \multirow{3}{*}{$\begin{array}{l}\text { Optimal behavior: } \\
\text { Partial repayment of the } \\
\text { original issue of equity, } \\
\text { financed both by profits in } \\
\text { period } t+1 \text { and disinvestment. }\end{array}$} & & \multirow{3}{*}{\multicolumn{2}{|c|}{$\begin{array}{l}\text { Non-optimal behavior: } \\
\text { Total repayment of the original } \\
\text { issue of equity, financed by } \\
\text { profits in period } t+1 \text { and a } \\
\text { reduced stock of capital. }\end{array}$}} \\
\hline & & & \\
\hline & & & \\
\hline
\end{tabular}

As explained above, our model cannot be used to derive parametric expressions for the short run costs of capital. We are still able to make considerable progress in illustrating and comparing the behavior of the two types of firms by resorting to numerical simulations. We will assume that there occurs an exogenous disturbance to the firms that raises the marginal productivity of capital, and that the resulting investment needs cannot be financed from retained earnings.

The $F$-case firm will then issue new equity sufficient to depress $\mu^{K}$ to unity. A growth path financed by retained earnings follows, and continues until the marginal valuation of capital has fallen to unity minus the dividend tax rate. For the $P$-case firm the starting condition is, likewise, that the marginal valuation of the injection of new equity equals unity, but this comes from two conceptually different sources: The first is the direct increase in the 
productive capacity of the firm, which is valued at the shadow price of capital, $\mu^{K}$. The second derives from the fact that the new equity enables the owner a tax-free return of capital, valued at the shadow price $\mu^{A}$. The condition $\mu^{K}+\mu^{A}=1$ then holds all along the firm's optimal path, with $\mu^{K}$ falling from its initial value in period $t$ in the range $1-\tau<\mu_{t}^{K}<1$, to its long-run value of unity minus the dividend tax rate.

We refer to Appendix B for a step-by-step account of the simulations. In general terms, we make use of the first order conditions to determine the development over time of the marginal valuation of capital, $\mu^{K}$, the pre-tax marginal rate of return, $F_{K}$, the capital stock, $K$, andin the $P$-case - the stock of new equity, $A$. We specify the firm's production function in the Appendix and we assume that the market rate of interest is 5 per cent.

The results of the simulations are illustrated in Figures 1-2 for a dividend tax rate of 30 percent $(\tau=0.3$ ). The cost of capital is initially 6.22 percent for the $P$-case firm, or 1.24 times the long-run cost of capital (of 5 percent), compared to 12.73 percent for the $F$-case firm, or 2.55 times the long-run cost of capital. As a result of these differences, there is a striking difference between the firms in the amount of new equity injected by the shareholders: The $P$ case firm starts its adjustment path with a capital stock which is more than four times as large as that of the $F$-case firm. Following the new issue, the $F$-case firm uses all profits for internal investment, and completes its growth path in 13 years. The adjustment phase of the $P$-case firm is of approximately the same length, but during the first half of this phase, the firm uses both current profits and disinvestment to repay the original new equity to the shareholders.

The gradual adjustment towards the long-run equilibrium obviously causes a loss in output, compared to a hypothetical case where the firms could immediately reach their new long-run capital stocks and output levels. The annual output losses, accumulated over the adjustment period, add up to 32 percent (of the hypothetical no-tax output level) for the $F$-case firm, and to 18.9 percent for the $P$-case firm, when the dividend tax rate is 30 percent $^{10}$.

\footnotetext{
${ }^{10}$ The numbers ignore the effect of discounting. The simulations depend on the parameters, and in particular on the tax rate. With a reduction in the dividend tax from 30 to 15 percent, for instance, the adjustment periods of both firms are shortened, but the effect is stronger for the $F$-case firm than for the $P$-case firm. The tax cut also reduces the cost of new equity and increases the size of the initial equity injection, for both firms. The distorting effects of dividend taxation remain considerably larger for the $F$-case firm than for the $P$-case firm. With a 15 percent tax on dividends, the output losses are 19.3 and 10.5 percent, respectively.
} 
Figure 1: The cost of capital following a new equity issue.

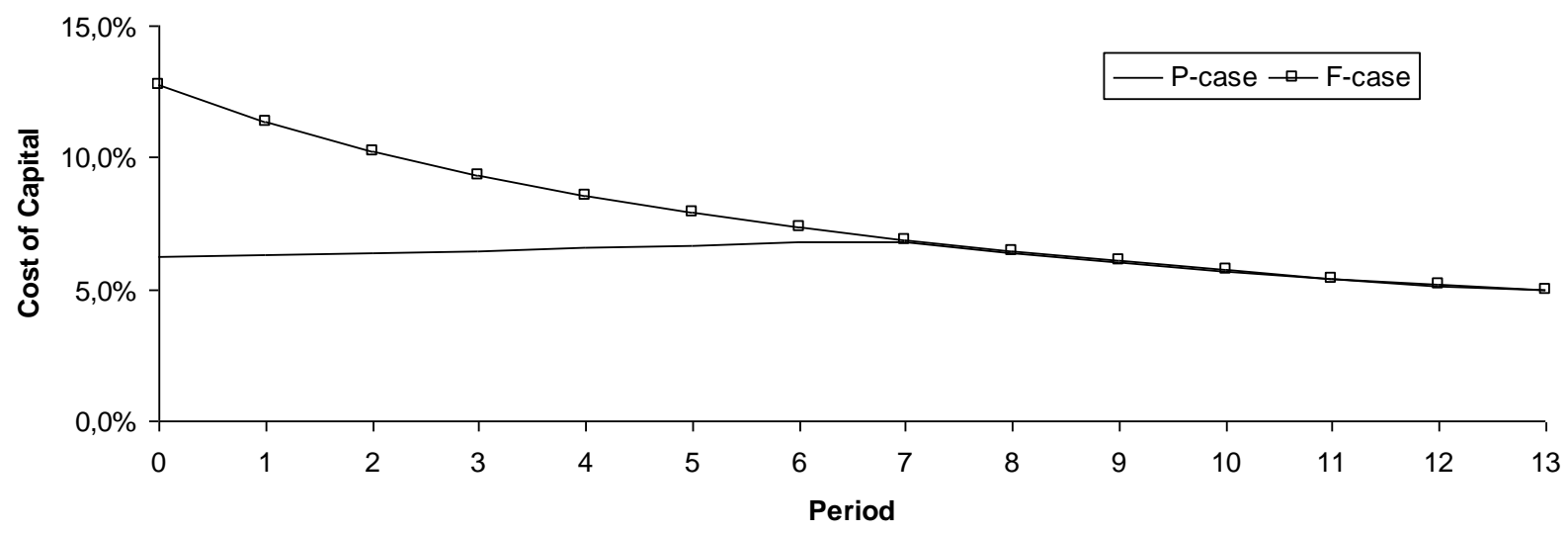

Figure 2: The development of the capital stock following a new equity issue.

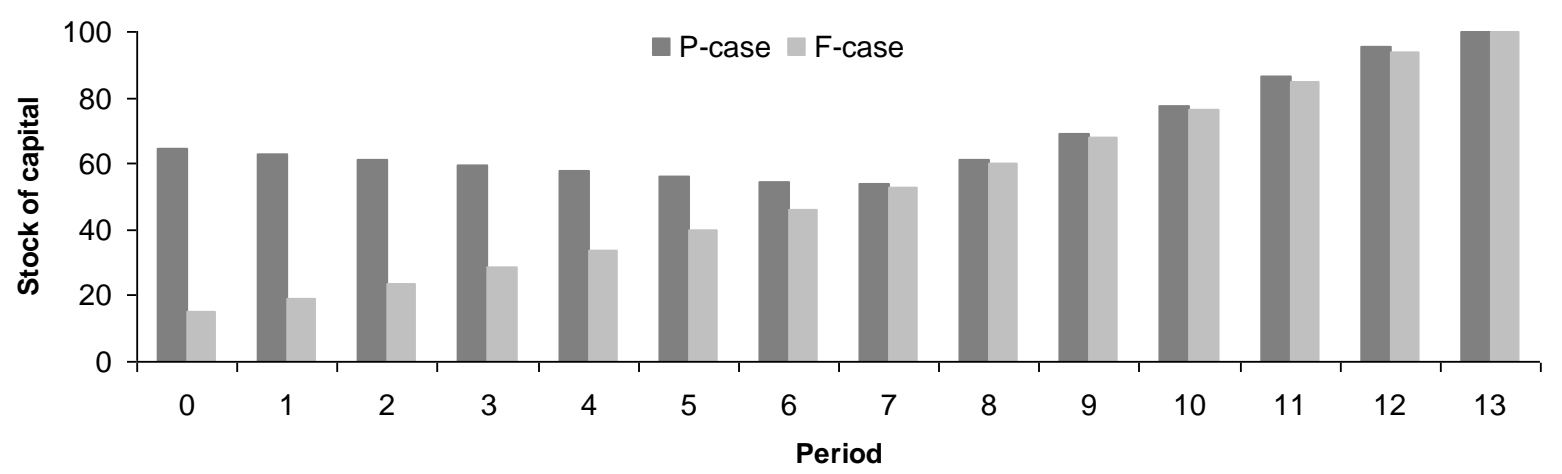

\section{Concluding comments}

This paper has examined how the distortions caused by dividend taxation depend on to what extent shareholders can recover their original equity injections without being subject to the dividend tax. We report that two different assumptions on this have been used in the literature, one where it is impossible for the firm to pay cash to its shareholders that is not taxed as dividends (the full equity trap, or F-case), the other where the shareholders are allowed a taxfree return of the original capital contributed through new issues (the partial equity trap, or $P$ case). To compare the two approaches, we set up a dynamic model of the firm where adjustments following an initial new share issue take place gradually with no dividends being paid until the firm is in a new long-run equilibrium. With a full equity trap, the firm embarks upon a growth path, using retained earnings as the source of funds, whereas with a partial equity trap, the growth path is preceded by a phase where the original capital injected into the firm is repaid to the shareholders. Our numerical simulations indicate a substantial difference 
between the two cases in the size of the initial equity injections, and a resulting difference in the output losses over the adjustment periods.

Though the results for the cost of new share issues derived in the earlier literature come out as special cases of our general model, real world tax law may obviously differ from the stylized $F$ - and $P$-case assumptions we have focused on in this paper. As a basic fact, however, we note that practically all countries allow shareholders a tax-free recovery of their initial equity following a winding-up decision, as the cost base of the shares is deductible against the taxable payout ${ }^{11}$. Moreover, there are several other old and new channels for a tax-free return of equity. Techniques such as share repurchases and combinations of splits and share redemptions, have gained in importance in most countries over the past decades. ${ }^{12}$ Though these procedures may trigger capital gains taxation, the original equity does escape tax, as long as the amount of any expenditure connected with the acquisition of the shares is deductible.

In the US, share repurchases appear to be especially important, even surpassing the value of dividends for certain years. Across Europe, the pattern has historically been different, and in several cases share repurchases long remained illegal. A European Union Council Directive first adopted in 1976, and later amended in November 1992, now regulates the use of share repurchases ${ }^{13}$. Present rules state that own shares acquired by a company may not exceed 10 percent of the subscribed capital. ${ }^{14}$ However, and importantly, the scope for share redemptions appears to be substantially less circumscribed, and subject only to the limitations set by the existence of a legally required minimum of share capital.

The assumption that firms can refund original contributions of capital out of earnings, may still be at variance with the law in many countries. In the United States, for example, payouts

\footnotetext{
${ }^{11}$ Communication from Sven-Olof Lodin, Professor of Fiscal Law at the University of Stockholm, and former President of International Fiscal Association. See also International Bureau of Fiscal documentation, IBFD Tax Research Platform 2015.

${ }^{12}$ See for example van Eije and Megginson (2008) and Skinner (2008).

13The Second Council Directive on Company Law, Directive 77/91/EEC on the formation of public limitedliability companies and the maintenance and alteration of their capital (13.12.1976). Amendments: Directive 92/101/EEC (23.11.1992).

${ }^{14}$ Elsewhere (Lindhe and Södersten (2009)), we have modelled the current EU rules regulating the use of share repurchases. When the tax code allows only some tax-free return of equity, our analysis indicates that the firm instead may embark upon an investment path, following the injection of capital. This initial growth phase is then followed by a phase of share repurchases, succeeded in turn by a second phase of investment on the firm's way towards long-run equilibrium. We find moreover that the less generous the scope for share repurchases, the longer is the first investment phase and the shorter is the phase of share repurchases.
} 
are taxable as dividends as long as the firm has positive accumulated earnings and profits. That is, payouts are treated as coming first from current and accumulated earnings, and taxable as dividends, until such funds are exhausted. Only then are additional payouts treated as non-taxable returns of capital.

From these casual observations, it is clear that the provisions for a tax-exempt return of original equity are varied and may differ between countries, but also that most countries do allow for at least some tax-exempt return of original capital. We may safely conclude, therefore, that any model, which explicitly or implicitly assumes that the shareholders cannot recover any of their original equity injections without being subject to tax (as in the F-casemodel), exaggerates the distortive effects of dividend taxation.

As the specific rules governing the shareholders' right to a tax-free return of the original capital affect the character of the firm's adjustments following a new share issue, they seem to be a subject worthy of further study. However, further progress in understanding the complexities in firm behaviour in the real world may not be just a matter of adding new or modified constraints to the underlying basic model. A more convincing theory of financial behaviour may eventually be needed, see for example Chetty and Saez (2010). Needless to say, and this is the important message of this paper, the tax incentives as such must be correctly understood and explicitly accounted for.

\section{References}

Auerbach, Alan J., 1979, Wealth Maximization and the Cost of Capital, Quarterly Journal of Economics, Vol.93(3), 433-446.

Auerbach, Alan J., 1983, Taxation, Corporate Financial Policy and the Cost of Capital, Journal of Economic Literature, Vol. 21, No. 3. (Sep., 1983), 905-940.

Auerbach, Alan J., 2002, Taxation and Corporate Financial Policy, in Handbook of Public Economics, Vol. 3, Ch. 19, 1251-1292. 
Auerbach, Alan J. and Kevin Hassett, 2002, On the Marginal Source of Investment Funds, Journal of Public Economics, Vol. 89, 205-232.

Auerbach, Alan J. and Kevin Hassett, 2005, The 2003 Dividend Tax Cuts and the Value of the Firm: An Event Study, NBER WP 11449.

Bradford, David F., 1981, The Incidence and Allocation Effects of a Tax on Corporate Distributions, Journal of Public Economics, Vol. 15, 1-22.

Brys, B. and Bovenberg, A.L., 2006, The Life Cycle of the Firm with Debt and Capital Income Taxes. CentER Discussion Paper, 2006-91, 1-29.

Chetty, Raj and Emmanuel Saez, 2007, An Agency Theory of Dividend Taxation, NBER WP 13538.

Chetty, Raj and Emmanuel Saez, 2010, Dividend and Corporate Taxation in an Agency Model of the Firm, American Economic Journal: Economic Policy (August 2010): 1-31

Directive 77/91/EEC (The Council of the European Communities).

Directive 92/101/EEC (The Council of the European Communities).

Devereux, M. P. and R. Griffith (1998), The Taxation of Discrete Investment Choices, The institute for Fiscal Studies, Working Paper Series No. W98/16.

Devereux, M. P. and R. Griffith (2003), Evaluating Tax Policy for Location Decisions, International Tax and Public Finance, 10, 107-126.

EU (2001), Company Taxation in the Internal Market, Commission staff working paper, $\operatorname{COM}(2001) 582$ final.

van Eije, Henk and William L. Megginson, 2008, Dividends and Share Repurchases in the European Union. Journal of Financial Economics, 87, 347-374.

IBFD Tax Research Platform (2015), International Bureau of Fiscal documentation. Jorgenson, Dale and Ralph Landau (eds.), 1993, Tax Reform and the Cost of Capital. An International Comparison, (The Brookings Institution, Washington, D.C.).

King, M. A., 1977, Public Policy and the Corporation (Chapman and Hall, London). 
King, M. A. and D. Fullerton, 1984, The Taxation of Income from Capital. A Comparative Study of the United States, the United Kingdom, Sweden and West-Germany (University of Chicago Press, Chicago).

Korinek, Anton and Stiglitz, Joseph E., 2009. Dividend Taxation and Intertemporal Tax Arbitrage, Journal of Public Economics, vol. 93(1-2), 142-159.

Lindhe, Tobias and Södersten, Jan, 2009, Dividend Taxation, Share Repurchases and the Equity Trap, CESifo Working Paper no. 2652.

Lindhe, Tobias and Södersten, Jan, 2012, The Norwegian Shareholder Tax Reconsidered, International Tax and Public Finance, vol.19 (3), 424-441.

OECD (1991), Taxing Profits in a Global Economy: Domestic and International Issues (OECD Publications, Paris).

Sinn, Hans-Werner, 1991, The Vanishing Harberger Triangle, Journal of Public Economics, Vol. 45, 271-299.

Sørensen, Peter Birch (ed.), 2004, Measuring the Tax Burden on Capital and Labor, CESifo Seminar Series, (MIT Press, Cambridge. Massachusetts, London).

Sørensen, P. B., 2005, Neutral Taxation of Shareholder Income, International Tax and Public Finance 12(6), 777-801.

Skinner, Douglas J.,2008, The Evolving Relation between Earnings, Dividends, and Stock Repurchases. Journal of Financial Economics, 87, 582-609.

\section{Appendix A: Technical details on optimal behavior}

This appendix explores the behavior of the $P$-case firm subsequent to a new share issue. A new share issue at time $t$ implies a positive stock of new equity, i.e. $A_{t}>0$, and, because of this, $\lambda_{t}^{A}=0$. Since $\mu^{K}=\mu^{D}$ (eq. 9) and by the first order conditions for $N$ and $A$ (eqs. (14) and (15)) we derive

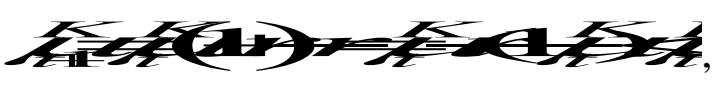


which may be interpreted to mean that whenever the stock of new equity is positive, the marginal valuation of capital will decrease from the current period to the next. Two alternative routes for the firm to follow subsequent to the new issue of equity at time $t$ may now be ruled out.

The first is where the firm would use the profits earned in period $t+1$ to pay dividends and maintain a positive stock of new equity, $A_{t+1}>0$. With $\lambda_{t+1}^{A}=0$, this would mean a continued reduction in the marginal value of capital, $\mu_{t+2}^{K}<\mu_{t+1}^{K}$. However, since payment of dividends requires that the marginal valuation of capital take its minimum value $\mu_{t+1}^{K}=1-\tau$, such a further reduction for time $t+2$ is impossible. We conclude therefore that the firm will not simultaneously pay dividends and keep a positive stock of new equity.

A second route, following the initial equity injection, would be to use current profits in period $t+1$ for additional investment, which would mean $K_{t+1}>K_{t}$. However, with $A_{t+1}>0$ and $\lambda_{t+1}^{A}=0$ as before, we derive

$$
F_{K_{t+1}}=\frac{r}{\mu_{t+2}^{K}}
$$

and since $\mu_{t+2}^{K}<\mu_{t+1}^{K}$ when $\lambda_{t+1}^{A}=0$, the cost-of-capital expression $F_{K_{t}}=r / \mu_{t+1}^{K}$ (eq. (18)) and equation (21) give that $K_{t+1}<K_{t}$. Hence, the firm's first order conditions imply a decrease in the capital stock. Also the second route, where the firm would use current profits to add to its capital stock must be ruled out.

The only feasible use of profits for period $t+1$ is therefore for repayment of the initial issue of equity. Assuming first that repayment takes place gradually, that is with $A_{t+1}>0$ and $\lambda_{t+1}^{A}=0$, we may use equations (20) and (21), to solve for the firm's capital stock, $K_{t+1}$ and, by using the budget constraint, also for the remaining stock of new equity, $A_{t+1}$. Since $\lambda_{t+1}^{A}=0$ implies that $K_{t+1}<K_{t}$, this partial repayment of the original issue of equity is financed both by current 
profits and disinvestment. Alternatively, the firm may choose to repay the entire issue of new equity at time $t+1$, by a further reduction in the stock of capital. However, such a reduction is not compatible with the first order conditions, since $\lambda_{t+1}^{A}>0$ when $A_{t+1}=0$, yields a lower cost of capital, implying a larger capital stock. Repaying the entire issue of equity at time $t+1$ is therefore ruled out.

We conclude that following an issue of new equity, the firm will use its profits neither to pay dividends, nor to add to its capital stock, but to repay the new equity. Repayment takes place gradually, and if profits in, say, time period $s-1$, is insufficient to return the remaining stock of new equity, that is $F\left(K_{s-1}\right)<A_{s-1}$, a positive stock will be kept for the following period, $A_{s}>0$. If, on the other hand, $F\left(K_{s-1}\right) \geq A_{s-1}$, the return of the initial equity issue will be completed in period $s$, possibly in conjunction with an addition to the capital stock (if $\left.F\left(K_{s-1}\right)>A_{s 1}\right)$.

\section{Appendix B: Technical details on the simulations}

For the $P$-case firm, we begin by choosing, tentatively, a starting value for $\mu_{t}^{K}$ in the feasible interval $1-\tau<\mu_{t}^{K}<1$. With $\lambda_{t}^{A}=0$, because of the new issue, we then determine $\mu_{t+1}^{K}$ from equation (20) in Appendix A and solve for the initial stock of capital from the cost-of-capital expression $F_{K_{t}}=r / \mu_{t+1}^{K}$ (eq. (18)). Since $\lambda_{t+1}^{A}=0$ when $A_{t}>F\left(K_{t}\right)$ (by the argument presented above), we use an updated version of equation (20) to compute $\mu_{t+2}^{K}$, and solve for the firm's capital stock, $K_{t+1}$, implicitly given by equation (21) in Appendix A. From the firm's budget constraint we also determine the remaining stock of new equity, $A_{t+1}$. This procedure is repeated until $F\left(K_{s-1}\right) \geq A_{s-1}$. The repayment of the initial equity issue is then completed in period $s$, possibly in conjunction with an addition to the capital stock (if $\left.F\left(K_{s-1}\right)>A_{s-1}\right)$. Having repaid the new equity, the firm will then use all of the profits earned in subsequent periods for investment, which means that we add $I_{v}=F\left(K_{v-1}\right), v=s+1, s+2 \ldots$. to the capital stock of the previous year, $K_{v-1}$. This "growth process" is continued until the marginal productivity of capital is equated to the rate of interest. If the marginal valuation of capital in the first round of simulations then happens to 
exceed (fall below) $1-\tau$, the whole procedure is repeated, using a lower (higher) starting value for $\mu_{t}^{K}$.

We compute the behavior of the $F$-case firm in a similar way. Since the firm's starting condition for period $t$ is that the marginal valuation of capital equals unity, we choose, tentatively, a value for the marginal valuation of capital in the next period, $\mu_{t+1}^{K}<1$. From (16), we then compute the initial capital stock, $K_{t}$, and by adding investment equal to $F\left(K_{t}\right)$, we obtain the capital stock and the marginal productivity of capital for the following year, $t+1$. This step-wise procedure is continued until the marginal productivity of capital equals the rate of interest. If then, as described above, the marginal valuation of capital happens to exceed (fall below) $1-\tau$, the whole simulation procedure is repeated, picking a lower (higher) starting value for $\mu_{t+1}^{K}$.

The simulations require a specification of the firm's production function. We let

$$
F(K)=K^{a}
$$

represent the firm's output, where $C$ determines the level of technology, and $\alpha$ is capital's share of output. With $\alpha=0.5, C=1$ and the market interest rate $r=0.05$, the long-run capital stock, as determined by $F_{K}=r$ (eq. (12)), is $K=100$. 